\title{
Analysis of the Sustainable Use of Geothermal Waters and Future Development Possibilities-A Case Study from the Opole Region, Poland
}

\author{
Joanna Boguniewicz-Zabłocka ${ }^{1, *}$, Ewelina Łukasiewicz ${ }^{1(\mathbb{D})}$ and Domenico Guida ${ }^{2}$ \\ 1 Department of Thermal Engineering and Industrial Facilities, Faculty of Mechanical Engineering, \\ Opole University of Technology, Prószkowska 76 Street, 45-758 Opole, Poland; e.lukasiewicz@po.edu.pl \\ 2 Departament of Industrial Enginering, University of Salerno, 84084 Fisciano, Italy; guida@unisa.it \\ * Correspondence: j.boguniewicz-zablocka@po.edu.pl
}

Received: 30 September 2019; Accepted: 22 November 2019; Published: 27 November 2019

\begin{abstract}
To achieve future energy policy goals, efficient energy systems based on geothermal water should be used more widely. The presented case study from the Opole region in Poland shows that there is great potential for investors interested in recovering geothermal energy in new facilities, for example to heat the domestic districts. The geological structure of the Opolskie Voivodship demonstrates the presence of rich geothermal water resources. Currently, these resources are not used for power engineering in the Opole Region, except for in a few passive houses. The existing boreholes have waters which reach temperatures ranging from 20 to $90{ }^{\circ} \mathrm{C}$ and prove that the region displays a high energy potential. The results from the calculations here show that the use of three low temperature geothermal intakes could be possible in three locations, namely in Grabin, in the area of Nysa, and in Wołczyn. This could generate thermal energy at a level of $34 \mathrm{GWh} /$ year. This corresponds to the heat demand of approximately 1150 detached houses with an area of 150 square meters. The results show that thermal energy for a medium size housing district can be supplied from a single borehole. The temperatures of water in the analyzed intakes determine their method of use as a lower heat source for heat pumps.
\end{abstract}

Keywords: geothermal water; sustainable energy production; thermal sources

\section{Introduction}

Implementation of the Renewable Energy Sources (RES) Directive (2009/28/EC) and the need for the limitation of emission effects, including smog, in urbanized areas result in increased interest in investments in the geothermal industry. Limiting the consumption of coal, oil, and gas reduces the emissions of greenhouse gases into the atmosphere and, consequently, does not contribute to global warming and environmental pollution. One of the most efficient and environmentally friendly types of renewable energy is geothermal energy. Both in Europe and around the world, geothermal waters and energy are most frequently used for the production of electric energy or for direct applications, such as heating, balneology, and agriculture. Additionally, thermal waters can be also useful, inter alia, in fish breeding, algae cultivation, industrial processing, including pasteurization, as well as in other applications such as snow melting, heating of runways at airports, etc. [1-3].

One of the countries where geothermal energy sources are increasingly being used is The Netherlands. Their main emissions goal is reducing $\mathrm{CO}_{2}$-equivalent emissions by $49 \%$ by 2030 , and by $95 \%$ by 2050 , in comparison to 1990 . Over the past ten years, the sector has grown rapidly, especially in the greenhouse horticultural sector, where geothermal energy is a priority, as the sector strives to become more sustainable $[4,5]$. An example of country where geothermal energy is constantly developing 
is Turkey. Due to the fact that Turkey is an energy-importing country, it needs to use its sustainable sources to reduce this costly dependence. For this reason, geothermal power is a wise choice, because it is economical, domestically obtained, and an environmentally friendly energy source. In addition, Turkey has many advantages regarding the use of geothermal energy, given its geographical location. In terms of geological configuration, Turkey lies on the Alpine-Himalayan belt, and the country has a very high geothermal energy potential of about 31,500 MW [6]. Geothermal energy can also reduce a country's trade deficit. In the USA, geothermal power plants in Nevada save the equivalent of 3 million barrels of oil a year, and also generate tax revenues for the government. In the Philippines, dependence on imported oil has decreased by $95 \%$ due to the introduction of an energy plan mainly involving the use of renewable energy sources [7-9].

New investments can be stimulated by change of policies and legal regulations of the state and European Union. Currently, the key program for the development of the RES industry in Poland, including geothermal power engineering, is the so called "Clean Air" Program (2018-2020) the objective of which is the improvement of energy effectiveness of buildings and reduction of emission of dusts and gases by existing or newly constructed detached residential buildings (Ministry of Energy 2018) $[9,10]$.

According to the study of the Polish Geothermal Association (Polska Geotermalna Asocjacja (PGA)), there are least $6600 \mathrm{~km}^{2}$ of geothermal waters with temperatures ranging from 27 to $125^{\circ} \mathrm{C}$ in Poland. In Poland (data for 2018) there were six geothermal heating plants supplying central heating networks in Podhale and in the Polish Lowlands: in Mszczonów, Uniejów, Poddębice, Pyrzyce, and Stargard. Geothermal waters were also used in ten spas and a dozen or so recreation centers. Geothermal heat from shallow depths is utilized with water source and ground source heat pumps [10]. Selected information regarding geothermal heating plants in Poland is given in Table 1. Figure 1 shows geothermal installations in Poland in 2017 [11].

In Mszczonów, (center of Poland, Masovian Voivodeship), geothermal water is extracted through one production well. The capacity of the source is around $60 \mathrm{~m}^{3} / \mathrm{h}$ at an outlet temperature of $42{ }^{\circ} \mathrm{C}$. The heating plant in Mszczonów has an installed geothermal capacity of $3.7 \mathrm{MWt}$, total amounting to $8.3 \mathrm{MWt}$. The production of geothermal heat in 2017 amounted to about $17 \mathrm{TJ}$. The geothermal production well supplies the heating network with heat, and also the Mszczonów baths with heat and water. Chilled water after passing through the heating and treatment system goes to the residents as potable water.

Table 1. Geothermal heating plants in Poland, 2017.

\begin{tabular}{|c|c|c|c|c|c|c|}
\hline Place & $\begin{array}{c}\text { Inflow } \\
\text { Water } \\
\text { Temperature } \\
{\left[{ }^{\circ} \mathrm{C}\right]}\end{array}$ & $\begin{array}{c}\text { Maximum } \\
\text { Mass Flow } \\
\text { of Flowing } \\
\text { Water } \\
{\left[\mathrm{m}^{3} / \mathrm{h}\right]}\end{array}$ & $\begin{array}{l}\text { Water } \\
\text { Mineralization } \\
{\left[\mathrm{g} / \mathrm{dm}^{3}\right]}\end{array}$ & $\begin{array}{c}\text { Installed } \\
\text { Geothermal } \\
\text { Thermal } \\
\text { Power } \\
\text { [MWt] }\end{array}$ & $\begin{array}{c}\text { Total } \\
\text { Installed } \\
\text { Thermal } \\
\text { Power } \\
\text { [MWt] }\end{array}$ & $\begin{array}{c}\text { Geothermal } \\
\text { Heat } \\
\text { Production } \\
\text { [TJ] }\end{array}$ \\
\hline Mszczonow & 42 & 60 & 0.5 & 3.7 & 8.3 & 17 \\
\hline Poddebice & 68 & 252 & 0.4 & 10 & 10 & 68 \\
\hline Podhale & $82-86$ & 960 & 2.5 & 40.7 & 82.6 & 512 \\
\hline Pyrzyce & 61 & 360 & 120 & 6 & 22 & 64 \\
\hline Stargard & 83 & 180 & 150 & 12.6 & 12.6 & 186 \\
\hline Uniejow & 68 & 120 & $6-8$ & 3.2 & 7.4 & 21 \\
\hline \multicolumn{4}{|c|}{ Total } & 76.2 & 142.9 & 868 \\
\hline
\end{tabular}

Own elaboration based on: Kępińska 2018. 


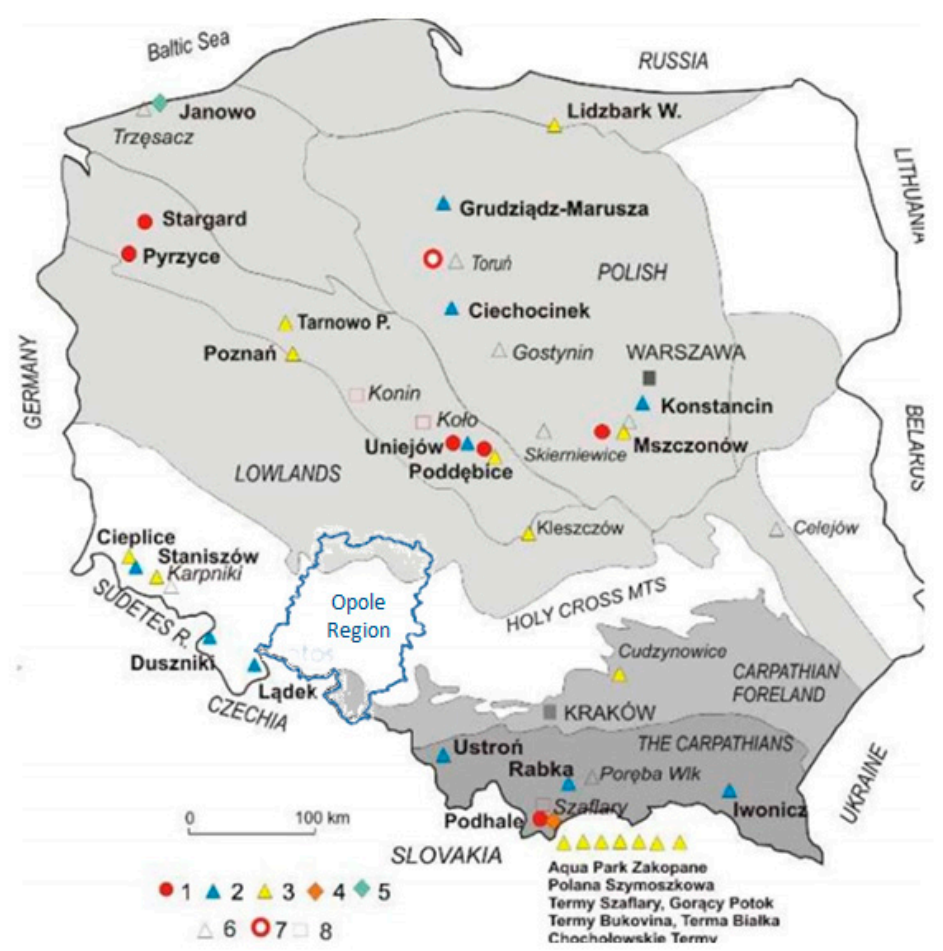

Figure 1. Geothermal installations in Poland, 2017:1-district heating plants, 2-health resorts, 3-recreation centers, 4-wood drying, 5-fish farming, 6-recreation centers in realization, 7-heating system at early stage, 8-some expected co-generation installations. Source: Kępińska 2019.

Three geothermal intakes are exploited in Podhale (Poland's southernmost region, is located in the foothills of the Tatra range of the Carpathian mountains), with an outflow temperature of $80-86{ }^{\circ} \mathrm{C}$, and a total capacity of $960 \mathrm{~m}^{3} / \mathrm{h}$. There are two injection wells into which water is injected after passing through the installation. The installed geothermal power is $40.7 \mathrm{MWt}$, while the total output of 82.6 MWt is achieved using two peak gas boilers and a gas-oil boiler and economizers. Geothermal heat production is around $512 \mathrm{TJ}$ per year, which is about $92 \%$ of total production. Central Heating $(\mathrm{CH})$ installation covers almost 35\% of the heat demand in Zakopane, and supplies several households in other nearby towns. The cooled stream of thermal water is reinjected into the reservoir, but part of the water is used for recreational purposes in Szaflary, or is discharged into a surface watercourse. This heating plant is one of the largest in continental Europe in terms of installed geothermal power, production, and sale of heat.

In Poddębice (center of Poland, Łódź Voivodeship), water is extracted through one production well, whose operational capacity is $252 \mathrm{~m}^{3} / \mathrm{h}$, and the temperature at the outlet reaches $71^{\circ} \mathrm{C}$. The installed geothermal power is $10 \mathrm{MWt}$ and the annual geothermal heat production is about $68 \mathrm{TJ}$. The intake allows heating of public buildings, schools, a hospital, and households. Geothermal water is also used in the pump room and recreational pools.

In Pyrzyce (Pomerania, north-western Poland), water is extracted through two production wells, and there are also two injection wells. The productivity of the sources is about $370 \mathrm{~m}^{3} / \mathrm{h}$, and the outlet water temperature is $61^{\circ} \mathrm{C}$. Installed geothermal power is about $22 \mathrm{MWt}$, and heat production is about $64 \mathrm{TJ}$ annually. This provides almost $90 \%$ of the heating needs of 13,000 people via a district heating network.

In Stargard (the West Pomeranian Voivodeship) geothermal water is extracted through one production well, and after use, it is pumped into one injection well. The source's operating capacity is $180 \mathrm{~m}^{3} / \mathrm{h}$ and the intake temperature is $87^{\circ} \mathrm{C}$. The geothermal power at this location is $12.6 \mathrm{MWt}$, and the heat production is $186 \mathrm{TJ}$ annually. In terms of annual production and sale of geothermal heat, this is the second largest installation in Poland (after Podhale). 
In Uniejów (Łódź Voivodeship, center of Poland) water is extracted through one production well, after which it is injected into two absorption wells. The operating capacity is $120 \mathrm{~m}^{3} / \mathrm{h}$ with an outlet temperature of $67^{\circ} \mathrm{C}$. Geothermal power at this location is $3.2 \mathrm{MWt}$, total power is 7.4 $\mathrm{MWt}$, while geothermal heat production is about $21 \mathrm{TJ}$. Geothermal water is used to supply both the central heating network and Term Uniejów. Part of the supply is also used to heat the football pitch and walking path. The installed geothermal heat power of the six given heating plants is annually about $76 \mathrm{MWt}$ (total-142 MWt), and the production of geothermal heat was around $868 \mathrm{TJ}$. These geothermal heating plants are constantly being modernized and expanded. Polish geothermal heating plants contribute to the reduction of harmful greenhouse gas emissions, meaning they are considered to be clean energy producers. Also in economic terms, geothermal heating plants are competing with conventional heat sources-prices are slightly higher than those from coal and comparable to prices from gas.

In Poland, health resorts that use geothermal water for their treatments are very popular. In ten cities in Poland there are such spas: Cieplice Ślaskie Zdrój, Lądek Zdrój, Duszniki Zdrój, Ciechocinek, Konstancin, Ustroń, Iwonicz Zdrój, Marusza near Grudziądz, Rabka Zdrój, and Uniejów. In addition, geothermal recreation centers and bathing areas have been opened in 14 places in Poland. In Poland there is one aquaculture of Atlantic salmon in Janów, using geothermal water. In Poland, geothermal heat is still used for drying wood, heating sports pitches and walking paths, cosmetics production, and the food industry. In Duszniki Zdrój, carbon dioxide has been recovered for many years from water that has a temperature of about $18^{\circ} \mathrm{C}$ at the outlet.

Ground source heat pumps are becoming more popular. According to the Kepińska (2018) and the Polish Organization for the Development of Heat Pump Technology in 2017, there is a total installed heating capacity of about $520 \mathrm{MW}$, and a heat output of $2600 \mathrm{TJ}$ using these pumps.

The above examples of applications of geothermal energy shows that Poland only has a few examples of geothermal water applications compared to Europe at large. The combined heat and power plants in Poland operate on a small scale, according to data from the European Geothermal Congress 2016, in 2015, Poland was 12th in Europe in terms of installed capacity from geothermal sources among 30 countries covered by statistics. Figure 2 shows geothermal heating and other direct uses in Poland and other European countries [12]. In 2017, there were 294 heating systems in Europe, of which only 6 were in Poland [10].

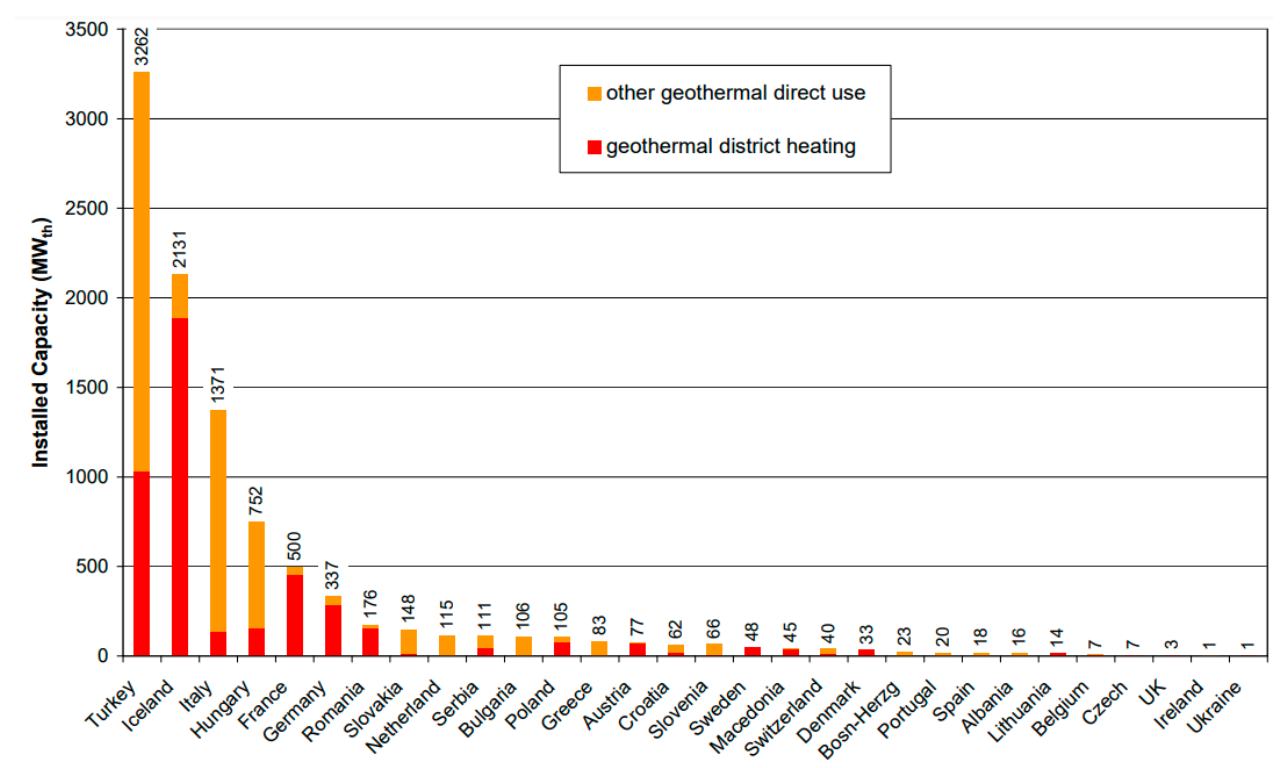

Figure 2. Geothermal heating and other direct uses in Poland and other European countries. Source: Antics et al. 2016. 
There is no geothermal heat and power plant in the Opole Region, but this area has rich resources of thermal deposits, especially low-temperature ones. The Opolskie Voivodeship has the potential for using thermal sources on a larger scale, however, investments have been withheld due to a lack of risk assessments. Determning the balance of benefits and losses when investing in thermal energy from thermal waters is crucial. This paper aims to estimate the efficiency of existing geothermal water wells in the Opolskie Voivodeship. Based on developed estimates, an assessment of the use of geothermal water resources, especially for heat production, is provided. Analysis of thermal water in the region from the perspective of thermal energy production for district heating and their environmental benefits $\left(\mathrm{CO}_{2}\right.$ emissions reduction) is discussed $[1,2,10]$.

\section{Case Study Description}

According to the World Health Organization (WHO), 36 out of the 50 cities in the European Union with the highest PM2.5 concentration are in Poland. Opoczno, Żywiec, Rybnik, and Pszczyna are the most polluted cities in Poland. In most of these places, smog is caused by so-called low emissions (significant accumulation of emitters up to 40 meters above ground level, in places with high building density, in a small area). Smog in Poland occurs mainly during the heating season (September-April). Poland often exceeds standards for PM10 and PM2.5 dust by over $3000 \%$. The report of the Ministry of Entrepreneurship and Technology shows that in 2016, smog prematurely killed almost 19 thousand people in Poland. Smog also leads to soil pollution, including for arable land. Research into so-called arable soil chemistry has shown an increase in the concentration of carcinogenic polycyclic aromatic hydrocarbons (PAHs) on land used for plant cultivation. Contaminants that create smog have many sources, but most of them are generated in various types of combustion processes. They are part of the so-called low emissions, i.e., pollutant emissions at an altitude of up to $40 \mathrm{~m}$. Central heating installations in Polish homes are often outdated, as they are low-power boilers in which residents use poor quality fuel, and people often burn municipal waste in private furnaces [13].

According to data from the Central Statistical Office of Poland, in 2015 combustion processes outside industry were the main source of emissions of carbon monoxide, dust, and non-methane volatile organic compounds, and were responsible for the emission of over $87 \%$ of polycyclic aromatic hydrocarbons and heavy metals [14].

Due to these problems with environmental pollution, it is necessary to take real action to reduce the emission of harmful gases into the atmosphere. Geothermal energy is ideal and is one of the cleanest sources of energy. The process produces no fumes or dust, waste, or other nuisances for the environment. The values of the upper and lower assessment thresholds for pollutants for which air quality assessments are required are given in Table 2 .

Table 3 presents a summary of the results of the assessment for selected pollutants taken into account in a five-year assessment (2013-2018) of the Opole region in terms of protecting human health. 
Table 2. Criteria for classification of regions in the five-year air quality assessment carried out to protect human health.

\begin{tabular}{|c|c|c|c|c|c|}
\hline \multirow{2}{*}{ Pollution * } & \multirow{2}{*}{$\begin{array}{l}\text { Averaging Time of } \\
\text { Concentrations }\end{array}$} & \multirow{2}{*}{$\begin{array}{c}\text { Level } \\
\text { Permissible/ } \\
\text { Target/ } \\
\text { Long Term } \\
\text { Goal }\end{array}$} & $\begin{array}{c}\text { Upper Assessment } \\
\text { Threshold }\end{array}$ & $\begin{array}{c}\text { Lower } \\
\text { Assessment } \\
\text { Threshold } \\
\end{array}$ & \multirow{2}{*}{$\begin{array}{c}\text { Permissible } \\
\text { Crossing } \\
\text { Frequency }\end{array}$} \\
\hline & & & $\begin{array}{c}\% \text { Of } \\
\text { Acceptable/Target/ } \\
\text { Long-Term Goal } \\
\text { Value [Unit] }\end{array}$ & $\begin{array}{c}\% \text { of } \\
\text { Acceptable/Target/ } \\
\text { Long-Term Goal } \\
\text { Value [Unit] }\end{array}$ & \\
\hline $\mathrm{SO}_{2}$ & $24 \mathrm{~h}$ & $125\left[\mu \mathrm{g} / \mathrm{m}^{3}\right]$ & $60 \% 75\left[\mu \mathrm{g} / \mathrm{m}^{3}\right]$ & $40 \% 50\left[\mu \mathrm{g} / \mathrm{m}^{3}\right]$ & \multirow{6}{*}{$\begin{array}{c}3 \text { times } \\
18 \text { times } \\
-\end{array}$} \\
\hline \multirow{2}{*}{$\mathrm{NO}_{2}$} & $1 \mathrm{~h}$ & $200\left[\mu \mathrm{g} / \mathrm{m}^{3}\right]$ & $70 \% 140\left[\mu \mathrm{g} / \mathrm{m}^{3}\right]$ & $50 \% 100\left[\mu \mathrm{g} / \mathrm{m}^{3}\right]$ & \\
\hline & calendar year & $40\left[\mu \mathrm{g} / \mathrm{m}^{3}\right]$ & $80 \% 32\left[\mu \mathrm{g} / \mathrm{m}^{3}\right]$ & $65 \% 26\left[\mu \mathrm{g} / \mathrm{m}^{3}\right]$ & \\
\hline $\mathrm{CO}$ & 8-h moving average & $10\left[\mathrm{mg} / \mathrm{m}^{3}\right]$ & $70 \% 7\left[\mathrm{mg} / \mathrm{m}^{3}\right]$ & $50 \% 5\left[\mathrm{mg} / \mathrm{m}^{3}\right]$ & \\
\hline $\mathrm{C}_{6} \mathrm{H}_{6}$ & calendar year & $5\left[\mu \mathrm{g} / \mathrm{m}^{3}\right]$ & $70 \% 3.5\left[\mu \mathrm{g} / \mathrm{m}^{3}\right]$ & $40 \% 2.0\left[\mu \mathrm{g} / \mathrm{m}^{3}\right]$ & \\
\hline $\mathrm{O}_{3}$ & $\begin{array}{l}\text { max. daily from } 8 \mathrm{~h} \\
\text { walking } \\
\text { concentrations }\end{array}$ & $120\left[\mu \mathrm{g} / \mathrm{m}^{3}\right]$ & $100 \% 120\left[\mu \mathrm{g} / \mathrm{m}^{3}\right]$ & & \\
\hline \multirow{2}{*}{ PM10 } & $24 \mathrm{~h}$ & $50\left[\mu \mathrm{g} / \mathrm{m}^{3}\right]$ & $70 \% 35\left[\mu \mathrm{g} / \mathrm{m}^{3}\right]$ & $50 \% 25\left[\mu \mathrm{g} / \mathrm{m}^{3}\right]$ & \multirow{4}{*}{$\begin{array}{l}35 \text { times } \\
-\end{array}$} \\
\hline & calendar year & $40\left[\mu \mathrm{g} / \mathrm{m}^{3}\right]$ & $70 \% 28\left[\mu \mathrm{g} / \mathrm{m}^{3}\right]$ & $50 \% 20\left[\mu \mathrm{g} / \mathrm{m}^{3}\right]$ & \\
\hline PM2.5 & calendar year & $25\left[\mu \mathrm{g} / \mathrm{m}^{3}\right]$ & $70 \% 17\left[\mu \mathrm{g} / \mathrm{m}^{3}\right]$ & $50 \% 12\left[\mu \mathrm{g} / \mathrm{m}^{3}\right]$ & \\
\hline $\mathrm{BaP}(\mathrm{PM} 10)$ & calendar year & $1\left[\mathrm{ng} / \mathrm{m}^{3}\right]$ & $60 \% 0.6\left[\mathrm{ng} / \mathrm{m}^{3}\right]$ & $40 \% 0.4\left[\mathrm{ng} / \mathrm{m}^{3}\right]$ & \\
\hline
\end{tabular}

Own elaboration based on: Five-year assessment of air quality in the Opolskie Region, 2019 [15].

Table 3. Classifications for regions obtained in the five-year assessment in 2013-2018.

\begin{tabular}{ccccccccc}
\hline $\begin{array}{c}\text { Zone } \\
\text { Name }\end{array}$ & $\mathrm{SO}_{2}$ & $\mathrm{NO}_{2}$ & $\mathrm{C}_{6} \mathrm{H}_{\mathbf{6}}$ & $\mathrm{CO}$ & $\mathrm{O}_{3}$ & PM10 & BaP(PM10) & PM2.5 \\
\hline $\begin{array}{c}\text { Opole } \\
\text { Opole }\end{array}$ & $1^{*}$ & 1 & 1 & 1 & $3 \mathrm{a}$ & $3 \mathrm{~b}$ & $3 \mathrm{~b}$ & $3 \mathrm{a}$ \\
Region & 1 & 1 & 2 & 1 & $3 \mathrm{a}$ & $3 \mathrm{~b}$ & $3 \mathrm{~b}$ & $3 \mathrm{~b}$ \\
\hline
\end{tabular}

* 1 -concentration in the zone below the lower assessment threshold; 2-concentration between upper and lower assessment threshold; $3 a$ - concentration above the upper estimation threshold but not exceeding the permissible level; $3 \mathrm{~b}$-concentration above the upper assessment threshold and at the same time above the permissible level. Own elaboration based on: Five-year assessment of air quality in the Opolskie Region, 2019.

The interest in geothermal energy in the Opolskie Voivodship is directed mostly at the installation of heat pumps to use this energy for heating purposes. An increased interest in construction of passive houses, using geothermal or solar energy for heating purposes, is observed. Perfect examples of this are: passive houses in Turawa, in Pogorzela near Opole, in Czarnowasy, as well as in Gród Rycerski in the commune of Byczyna. All these facilities have heat pumps used for heating purposes. The communes of Nysa, Pokój, and Wołczyn already have studies regarding the assessment of hydrothermal conditions, from which it has become clear that use of geothermal waters for heating purposes is possible. Figure 3 show the share of geothermal energy from RES in the production of heat and electricity in the Opole region [16]. Geothermal energy in Poland has the highest technical potential for heat out of all renewable sources, estimated at $1512 \mathrm{PJ} /$ year, which accounts for approximately $30 \%$ of the national demand for heat. The demand for thermal energy in the Opolskie Voivodship is $11.684 \mathrm{GWh} /$ year [17]. The hydrogeological conditions in the Opolskie Voivodship indicate the presence of three regions in which mineral waters can be used as a balneological raw material: the northern part of the Opolskie Voivodship, the Kędzierzyn Koźle region, and the Nysa poviat [18]. In the region of Kędzierzyn- Koźle and in the poviat of Namysłów and Kluczbork, there are waters reaching a temperature of circa $20^{\circ} \mathrm{C}$, thus being mostly suitable for bath therapies. However, near Nysa, there are thermal waters with temperatures ranging from 30 to $85{ }^{\circ} \mathrm{C}$. Therefore, in addition to balneology, they can be used for heating purposes $[19,20]$. 


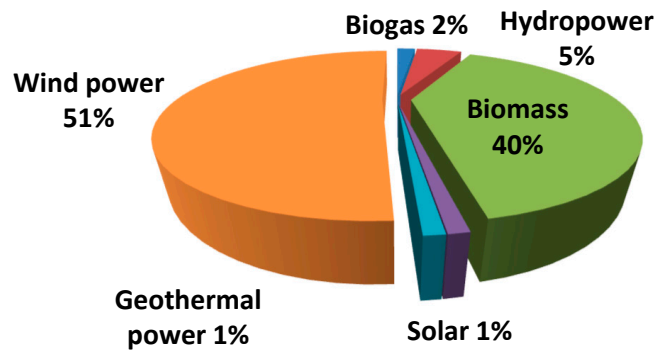

Figure 3. Structure of the share of geothermal energy from Renewable Energy Sources in the production of heat and electricity in the Opole region in 2015. Source: Own elaboration based on: Marshal Office of the Opolskie Voivodeship, Department of Agriculture and Rural Development.

For usage purposes, the most interesting areas are those where the water temperature in cicra 1500-3000 m deep boreholes reaches $60-100{ }^{\circ} \mathrm{C}$ and the capacity of a single borehole is at least $50 \mathrm{~m}^{3} / \mathrm{h}$. Land surveys conducted over the years show that such deposits can be found in the Opolskie Voivodship [21-23]. According to the collected information, communes of Praszka, Dobrodzien, Byczyna, and Polska Cerkiew are planning investments using these forms of renewable energy [17].

Presence of geothermal waters in the Opole Region is connected with the complex of sub-Cenozoic rocks and the water parameters depend on the features of the geological structures in the given unit area. The Opolskie Voivodship is located within the area of geological units such as: Pre-Sudeten Block, Silesian-Moravian Variscides, Opole Cretaceous, and Pre-Sudeten Monocline [24]. Figure 4 presents the geological map without Cenozoic deposits for the Opolskie Voivodship:

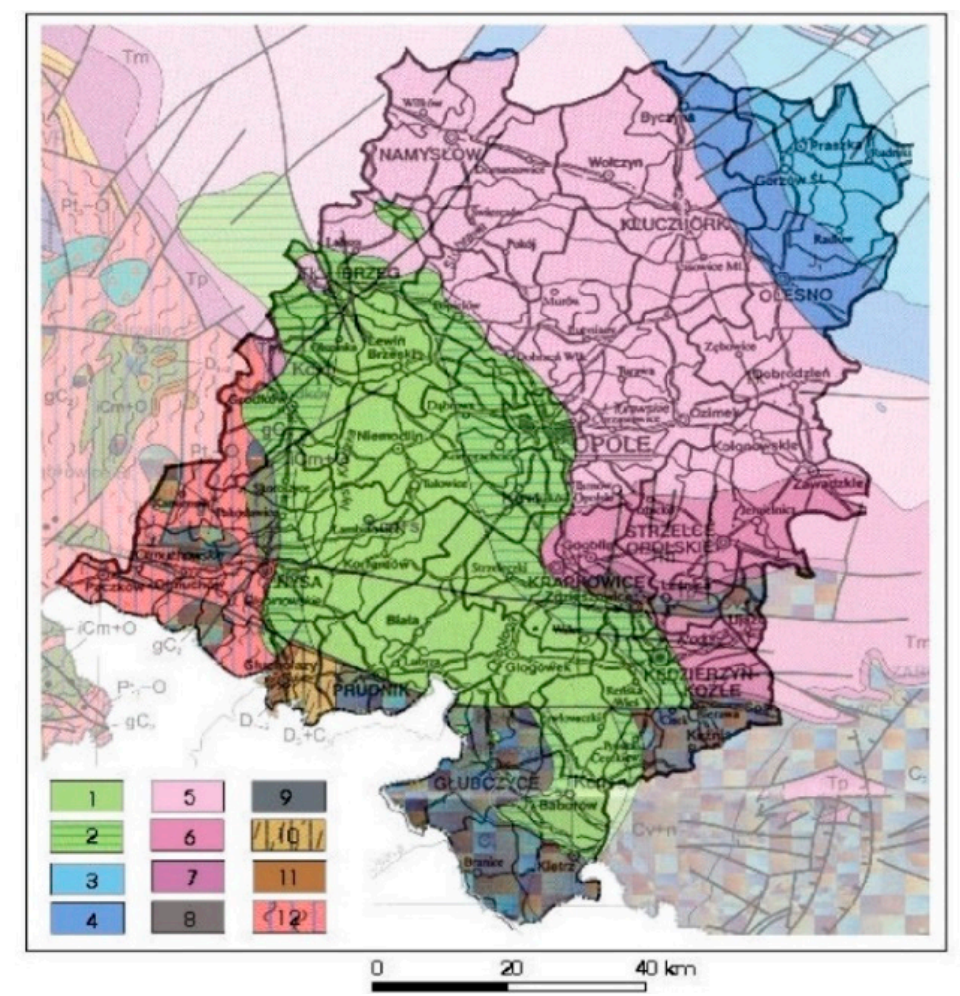

Figure 4. Opole Province-geological map without Cenozoic work. 1-Late Cretaceous (Coniacian, Santonian); 2-Late cretaceous (Cenomanian, Turonian); 3-Middle Jurassic; 4-Lower Jurassic; 5-Upper Triassic; 6-Middle Triassic; 7-Lower Triassic; 8-Upper Carboniferous; 9-Lower Carboniferous; 10-Late Devonian and Lower Carboniferous; 11-Early and Middle Devonian; 12-Late Proterozoic-Ordovician. Source: Study For The Development Of Energy Systems In Opolskie Voivodeship 2015. 
The Pre-Sudeten Block is located in the western part of the voivodship on the sub-Cenozoic surface and contemporary Quaternary surface in the region of Paczków, Otmuchów, and Kamiennik, as well as in the Opole Cretaceous substrate. It has been projected that crevice geothermal waters may be present from the depth of approximately $1500 \mathrm{~m}$. The eastern part of the Pre-Sudeten Block was identified through boring works conducted between Wrocław and Opole. In this region, in the structural borehole Oder 5/1 in Grabin, at the depth of $545 \mathrm{~m}$ under the Cretaceous in the Proterozoic gneisses, an artesian flow with a $25 \mathrm{~m}$ water column was found, with outflow temperature of $31.4{ }^{\circ} \mathrm{C}$. The capacity of this borehole is $150-200 \mathrm{~m}^{3} / \mathrm{h}$, it is a brine with $10 \mathrm{~g} / \mathrm{dm}^{3}$ mineralization, with high $\mathrm{CO}_{2}$, $\mathrm{Na}$, and $\mathrm{Mg}$ content. In the northern part of the Opolskie Voivodship, in the town of Wołczyn, the water from Wołczyn VIIA intake is classified as $2.2 \%$ mineral, chlorine-sodium-calcium, thermal water with dissolved substance content at the level of $23.6 \mathrm{~g} / \mathrm{dm}^{3}$, with source efficiency of $8 \mathrm{~m}^{3} / \mathrm{h}$ and an outlet temperature of $37^{\circ} \mathrm{C}$. On the basis of the calculations [25,26] for the poviat of Nysa (southern region of the voivodship) for the source efficiency of $15 \mathrm{~m}^{3} / \mathrm{h}$ and water temperature of $85^{\circ} \mathrm{C}$, the energy production can be $22.5 \mathrm{GWh} /$ year. In the authors' opinion, however, these studies are not correct since the temperature of water return to the source was erroneously adopted as absolute 0 . Therefore, the paper section "Calculations" presents correct calculations for the thermal resources found near Nysa. In the Silesian-Moravian zone, the geological structure of the region of Prudnik, Głubczyce, and Kedzierzyn- Koźle indicates the presence of limestone at the depth of at least $3000 \mathrm{~m}$ and water with temperatures exceeding $90^{\circ} \mathrm{C}$. The geological structure of the Opolskie Voivodship creates an opportunity to find efficient levels of geothermal waters based on which geothermal plants could be erected in multiple towns of the voivodship [27-29].

\section{Results and Discussion}

\subsection{Analysis of possible Thermal Energy}

Thermal power and the energy that can be generated by a geothermal heating boiler station was estimated for three towns: Nysa, Wołczyn, and Grabin. Today, these intakes are not used for any purpose, mainly due to economical reasons and a lack of investors. The thermal power and energy supplied by the geothermal heating boiler station can be approximated if the following are known: mass $m$ of the water from the deposit, temperature $T_{1}$ of the water from the intake bore, temperature $T_{2}$ of the return water pumped to the absorbent hole (if there is no injection well, it can be transported to a retention tank). The calculations were carried out for three thermal water intake boreholes near Nysa, in Grabin and Wołczyn. It was assumed that the temperature for the return water is the same on all cases and is equal to $20^{\circ} \mathrm{C}$. It was also assumed that heat efficiency of the geothermal sources is assessed when treating them as the lower heat source for the heat pumps. Heat losses in transfer and method of heat receipt from the source for these estimates are negligible. Heat power can be calculated from the formula:

$$
\dot{Q_{G}}=\dot{m} \times c_{p} \times \Delta T
$$

where:

$\dot{Q}_{G}$-thermal power, $\mathrm{W}$

$\dot{m}$-mass flow of flowing water, $\mathrm{kg} / \mathrm{s}$

$c_{p}$-average specific heat of water, $\mathrm{J} / \mathrm{kgK}$

$T_{1}, T_{2}$ - designed supply and return temperatures, $\mathrm{K}$.

3.2. Nysa

$$
\begin{gathered}
\text { Data }: m=15 \frac{m^{3}}{h}, c_{p}\left(85^{\circ} \mathrm{C}\right)=4201 \frac{J}{\mathrm{kgK}^{\prime}}, T_{1}=85^{\circ} \mathrm{C} T_{2}=20^{\circ} \mathrm{C} \\
\dot{Q_{G}}=\dot{m} \times c_{p} \times \Delta T=1135 \mathrm{~kW},
\end{gathered}
$$


During the year, thermal energy production may amount to:

$$
Q_{R}=1,13 M W \times 365 \times 24 \approx 9899 M W h / \text { year }
$$

The annual demand (D) for thermal energy for a detached house with a usable area of approximately $150 \mathrm{~m}^{2}$ is $30 \mathrm{MWh}$. This heating boiler station will be able to supply sufficient amount of heat based on the equation:

$$
S=\frac{Q_{R}}{D} \approx 330
$$

for detached houses.

Assuming that the demand for heat in buildings with normal thermal insulation is at a level of $80 \mathrm{~W} / \mathrm{m}^{2}$, one could state that the power in the above mentioned heating boiler station will supply heat to facilities with an area $(\mathrm{N})$ of:

$$
N=\frac{P}{A}=14200 m^{2},
$$

\subsection{Grabin}

$$
\begin{gathered}
\text { Data : } m=200 \frac{m^{3}}{h}, c_{p}\left(85^{\circ} \mathrm{C}\right)=4174 \frac{\mathrm{J}}{\mathrm{kgK}}, \mathrm{T}_{1}=31.4{ }^{\circ} \mathrm{C} \mathrm{T}_{2}=20^{\circ} \mathrm{C} \\
\dot{Q_{G}}=2,64 \mathrm{MW} \\
Q_{R} \approx 23,12 \mathrm{GWh} / \text { year } \\
S \approx 771 \\
N \approx 33041 \mathrm{~m}^{2} .
\end{gathered}
$$

\subsection{Wotczyn}

$$
\begin{gathered}
\text { Data }: m=8 \frac{m^{3}}{h} c_{p}\left(37^{\circ} \mathrm{C}\right)=4174 \frac{J}{\mathrm{kgK}} T_{1}=37^{\circ} \mathrm{C} T_{2}=20^{\circ} \mathrm{C} \\
\dot{Q_{G}}=0,157 \mathrm{MW} \\
Q_{R} \approx 1,3 \mathrm{GWh} / \text { year } \\
S \approx 46 \\
N \approx 1971 \mathrm{~m}^{2} .
\end{gathered}
$$

Table 4 presents tabulation of results for the town of Nysa, Grabin, Wołczyn, while Figure 5 presents annual thermal efficiency for the above geothermal intakes.

Table 4. Tabulation of results for the town of Nysa, Grabin, and Wołczyn.

\begin{tabular}{ccccc}
\hline Intake & $\begin{array}{c}\text { Thermal Power } \\
\boldsymbol{Q}_{G}[\mathbf{M W}]\end{array}$ & $\begin{array}{c}\text { Thermal Energy } \\
\boldsymbol{Q}_{R}[\mathrm{GWh} / \text { year }]\end{array}$ & $\begin{array}{c}\text { Number of Heated } \\
\text { Homes/Years } \\
\mathbf{S}[-]\end{array}$ & $\begin{array}{c}\text { Area of Heated } \\
\text { Objects } \\
\mathbf{N}\left[\mathbf{m}^{2}\right]\end{array}$ \\
\hline Nysa & 1.13 & 9.9 & 330 & 14.200 \\
Grabin & 2.64 & 2.12 & 771 & 33.041 \\
Wołczyn & 0.157 & 1.3 & 46 & $1971^{1}$ \\
\hline
\end{tabular}

${ }^{1}$ Source: Author's own elaboration. 


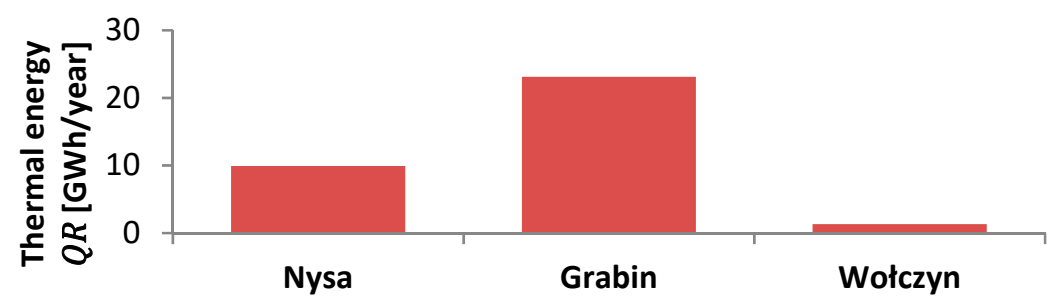

Figure 5. Annual thermal efficiency for geothermal intakes Nysa, Grabin, and Wołczyn. Source: Author's own elaboration.

The results obtained for the three locations allow analysis of possible district heating with heat energy from existing thermal wells. Grabin is a small village with about 160 households. Considering that the heat energy obtained from the thermal intake in this town could cover the demand for heat energy for about 770 households, the obtained energy exceeds the demand of the village by almost 5 times. For the city of Nysa, it was calculated that nearly $3 \%$ of approximately 11,000 households could only obtain thermal energy from a thermal source. For the slightly smaller city of Wołczyn, the heat energy obtained from the well could cover, as in the case of Nysa, about 3\% of the number of households. At present, there are no investors who would deal with the construction of such heat and power plants, which is due to the long reimbursement period of investment costs. However, given the trends prevailing in Europe and in the world and at the same time the need to search for "clean" energy sources, the possession of such large resources of thermal waters is good for Poland (70-80\% of the country).

Table 5 presents the annual emission from a detached house with usable area of approximately $150 \mathrm{~m}^{2}$ with the building energy standard about $90 \mathrm{kWh} / \mathrm{m}^{2}$ year with thermal insulation for selected fuels [30]. As estimated, the thermal energy for 330 houses from Nysa will allow $\mathrm{CO}_{2}$ emissions to decrease by $4072 \mathrm{t} /$ year compared to emissions from heating houses using coal, and by 2073 tonnes of $\mathrm{CO}_{2} /$ year for houses heated by natural gas.

Table 5. The annual emission from a detached house.

\begin{tabular}{|c|c|c|c|c|c|c|}
\hline & & $\begin{array}{c}\mathrm{CO}_{2} \\
{[\mathrm{~kg} / \text { year }]}\end{array}$ & $\begin{array}{c}\mathrm{CO} \\
{[\mathrm{kg} / \text { year }]}\end{array}$ & $\begin{array}{c}\text { PM }(10,2,5) \\
{[\mathrm{kg} / \text { year] }}\end{array}$ & $\begin{array}{c}\mathrm{SO}_{2} \\
{[\mathrm{~kg} / \text { year] }}\end{array}$ & $\begin{array}{c}\mathrm{NO}_{x} \\
{[\mathrm{~kg} / \text { year] }}\end{array}$ \\
\hline Natural gas & $\begin{array}{l}\text { Old-type } \\
\text { boiler, } \\
\text { constant } \\
\text { temperature }\end{array}$ & 6283 & 3.71 & 0.01 & 0.10 & 2.72 \\
\hline Coal & $\begin{array}{l}\text { The boiler } \\
\text { for fine coal }\end{array}$ & 12342 & 508.18 & 12.75 & 69.69 & 10.16 \\
\hline
\end{tabular}

Own elaboration based on: Emission calculator for detached houses.

Focusing on the profitability of using mineral deposits for energy purposes, it is primarily important to correctly identify geological parameters, such as the temperature of geothermal waters, mineralization, depth of mineral deposit retention and operational efficiency. The estimated thermal efficiency of geothermal deposits for three existing wells shows its energy potential. Figure 6 shows the potential of geothermal production depending on operational efficiency and temperature differences. 


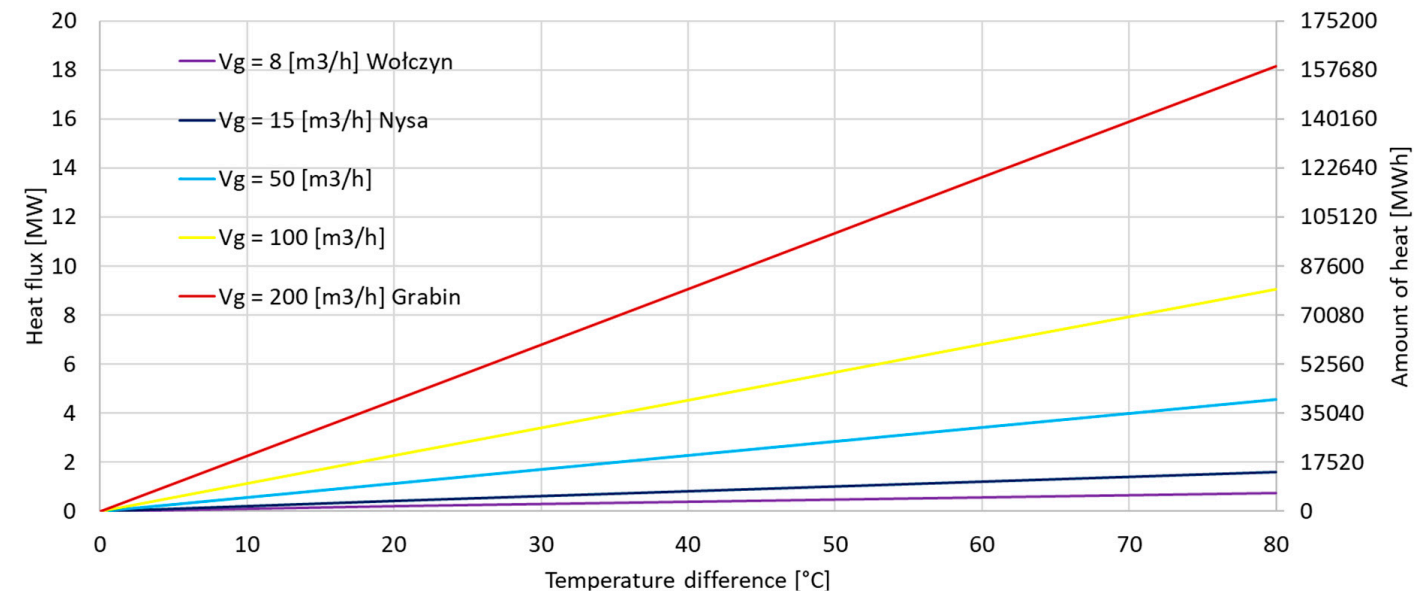

Figure 6. Possibilities of geothermal production depending on operational efficiency and temperature difference. On the left is the instantaneous power in MW, on the right the amount of heat that can be obtained per year. Source: based on own data and Grzesiak 2007.

When we relate the three sources discussed in the chart on Figure 6, it can be observed that the heat flux received from Wołczyn has the smallest efficiency for heat production, whereas one could expect a high amount of heat in Grabin. As described by other authors, the most favorable option is the extraction and energy management of waters lying at a depth not exceeding $2000 \mathrm{~m}$, with a temperature above $65^{\circ} \mathrm{C}$ and salinity not exceeding $30 \mathrm{~g} / \mathrm{dm}^{3}[2,31]$. The thermal energy from thermal waters could be used in public and multi-family buildings for district heating and could replace coal frequently used for building heating systems in Poland. The utilization of geothermal energy system benefit in the conservation of fossil fuels and reduction in emission of such pollutants as $\mathrm{CO}_{2}, \mathrm{SO}_{2}$, and $\mathrm{NOx}$.

\section{Investment factors related to the use of geothermal waters}

In the cases presented here, there are already boreholes, the heat plant installations are missing, and as many authors suggest, the most expensive part of the investment in the construction of a geothermal power plant is the execution of a test well [1,24,32].

Other factors that determine the use of geothermal energy to produce heat or power are: geological conditions, deposit water parameters, thermodynamic efficiency of applied processes, as well as economic calculations and the structure of heat recipients. The principle of using steam and geothermal water consists in the first case of using steam to drive turbines connected by a rotary shaft to a generator producing electricity. On the other hand, geothermal water extracted through boreholes releases heat in heat exchangers or heat pumps, which is then transferred to the medium supplying the heating network.

Increasingly, low-enthalpy deposits are also used to produce electricity in binary systems based on Rankine's thermal cycle. The working medium with an evaporation temperature lower than the boiling point of water is evaporated during heat exchange with geothermal water, after which it passes through a steam turbine connected to the generator, similarly to using geothermal vapor deposits. The used steam is condensed in the condenser and again flows to the evaporator. Below are three systems that are very popular in Europe for geothermal intake [33-36].

Authors analyzed a geothermal plants system for possible use in selected regions. The different plants differ according to the state of aggregation (liquid or vapor), and to the temperature of the geothermal fluid. In dry steam power plants, the water is in the dry steam state, so the temperature must be at least $150^{\circ} \mathrm{C}$. The geothermal steam extracted from the production well is sent directly to the turbine. At the end of the condensation phase, the water is reinjected into the geothermal well. 
Due to the high temperatures, these types of plant are not suitable for the geothermal sites analyzed here. Binary cycle power plants use water at a temperature between 85 and $170{ }^{\circ} \mathrm{C}$, a second fluid with low boiling point is used, which is evaporated by heat exchange with geothermal water and then made to expand in the turbine. The reference cycle used is the organic Rankine cycle is very similar to the Rankine cycle, but with the difference that the vector fluid is an organic fluid. Using this cycle, it is possible to generate electricity economically from lower temperatures than with direct systems. Due to the lower temperatures, this plant could be used on the Nysa site.

Hot waters, which appear to be present in large parts of all continents, can also be exploited and offer interesting prospects, especially in space heating and industrial processes. A geothermal heat pump or ground source heat pump (GSHP) is a central heating and/or cooling system that transfers heat to or from the ground. Heat pumps provide winter heating by extracting heat from a source and transferring it into a building. Heat can be extracted from any source, no matter how cold, but a warmer source allows higher efficiency. A ground source heat pump uses the top layer of the earth's crust as a source of heat, thus taking advantage of its seasonally moderated temperature [37]. The net thermal efficiency of a heat pump should consider the efficiency of electricity generation and transmission, which is typically about $30 \%$. Another direct use is the heating of individual commercial and residential structures from a pumped well or downhole heat exchanger. This is by far the simplest form of direct geothermal heating. In the case of a pumped well, the geothermal water is pumped from the well and to the structure where a heat exchanger transfers the energy from the geothermal source to an in-building system. The geothermal water is then returned to the aquifer via an injection well or disposed to the surface. Where high enough temperatures are encountered at a relatively shallow depth, e.g., 20-200 meters, downhole exchangers may be used, replacing the need for pumping of the geothermal fluid from the reservoir as well as need for a disposal system. The use of geothermal energy for space heating is the best solution for the cities of Nysa, Grabin, and Wołczyn because as a result of the relatively low temperatures of the analyzed sources, the production of electric energy would be difficult to achieve. Furthermore, space heating has lower plant costs, so it is also suitable for sites with reduced power. Other uses of geothermal sources include greenhouse and covered ground heating, aqua culture ponds, and raceway heating. A particular use is to prevent agricultural crops from drying such as various grains, vegetables and fruit crops. In some cases, it is also possible to carry out industrial process heating. Some examples of this are concrete curting, bottling of water and carbonated drinks, milk pasteurization, leather industry, chemical extraction, $\mathrm{CO}_{2}$ extraction, pulp, and paper processing, iodine and salt extraction, and borate and boric acid production [38-40].

\section{Conclusions}

The need for sustainable development for removable energy sources, which is growing in Poland and in the world, will also force investments in geothermal energy in the coming years. This paper analyzes the Opolskie Voivodship and its high potential for using geothermal resources as sources of heat energy. Currently, the geothermal resources in the Opole Region are not used, except for a few households and facilities. The resources found in this region are mostly low-temperature resources of geothermal waters that could be used, first and foremost, for therapeutic, balneological and heating purposes. The estimated value of heat production using heat pumps in the Opole Voivodship in years 2010-2012 was 13.84 GWh. It arises from the conducted calculations that the highest thermal power potential occurs in Grabin. For example, 2.64 MW can be supplied by the geothermal resources in Grabin and the power of this heating boiler station can supply heat to facilities with an area of $33,041 \mathrm{~m}^{2}$. The annual production of thermal energy for this town can be $23.12 \mathrm{GWh} /$ year, which allows for the supply of heat to 771 detached houses. The thermal power for the intake near Nysa is $1.13 \mathrm{MW}$, thus, it can supply heat for facilities covering the area of $14,200 \mathrm{~m}^{2}$. The annual production of thermal energy for this town can be $9.9 \mathrm{GWh} /$ year, which allows for the supply of heat to 330 detached houses. The thermal power for the intake in Wołczyn is $0.157 \mathrm{MW}$, thus, it can supply heat for facilities covering the area of $1971 \mathrm{~m}^{2}$. The annual production of thermal energy for this town could be $1.3 \mathrm{GWh} /$ year, 
which allows for the supply of heat to 46 detached houses. The above estimates confirm that the Opolskie Voivodship has geothermal water resources that could be used as sustainable energy sources at the lower heat source in heat pumps. The main reason for the lack of investments in development of geothermal engineering in the region are the very high costs of intake of such waters and the performance of the test bore. However, in the light of the contemporary challenges connected with the use of renewable energy sources and bearing in mind necessary protection of the air and natural environment, an increase of the share of geothermal sources in thermal power engineering, both in the Opole Region and in the entire country, is predicted.

Author Contributions: Conceptualization, E.Ł. and J.B.-Z.; methodology, E.Ł. and J.B.-Z.; formal analysis, D.G.; investigation, J.B.-Z.; resources, D.G.; writing—original draft preparation, E.Ł.; writing—review and editing, J.B.-Z.; supervision, D.G.

Funding: This research received no external funding.

Conflicts of Interest: The authors declare no conflict of interest.

\section{References}

1. Podgórni, E. Application of Flokor products in geothermal water treatment in Poland. Innov. Opole-Eff. Coop. Sci. Econ. 2015, 43, 132-142.

2. Kępińska, B. Geothermal Energy Country Update Report from Poland, 2010-2014. In Proceedings of the World Geothermal Congress, Melbourne, Australia, 25 April 2015; pp. 19-25.

3. European Council. Directive 2009/28/EC of the European Parliament and of the Council of 23 April 2009 on the Promotion of the Use of Energy from Renewable Sources and Amending and Subsequently Repealing Directives 2001/77/EC and 2003/30/EC (PDF); European Council: Brussels, Belgium, 2009.

4. Schof, F.; Hout, M.; Zanten, J.; Hoogstraten, J.W. Master Plan Geothermal Energy in the Netherlands. A Broad Foundation for Sustainable Heat Supply; Stichting Platform Geothermie: Delft, The Netherlands, 2018.

5. Provoost, M.; Albeda, L.; Godschalk, B.; Werff, B.; Schoof, F. Geothermal Energy Use, Country Update for The Netherlands. In Proceedings of the European Geothermal Congress, The Hague, The Netherlands, 11-14 June 2019.

6. Canka Kilic, F. Geothermal Energy in Turkey. Energy Environ. 2016, 27, 1-17.

7. Dursun, B.; Gokcol, C.H. The role of geothermal energy in sustainable development of Turkey. Energy Explor. Exploit. 2012, 2, 207-222. [CrossRef]

8. Shortalla, R.; Davidsdottirb, B.; Axelssonc, G. Geothermal energy for sustainable development: A review of sustainability impacts and assessment frameworks. Renew. Sustain. Energy Rev. 2015, 44, 391-406. [CrossRef]

9. Colmenar-Santos, A.; Palomo-Torrejón, E.; Rosales-Asensio, E.; Borge-Diez, D. Measures to Remove Geothermal Energy Barriers in the European Union. Energies 2018, 11, 3202. [CrossRef]

10. Kepińska, B. Overview of the state of the use of geothermal energy in poland in the years 2016-2018. Tech. Poszuk. Geol. Geoterm. Zrównoważony Rozw. 2018, 1, 11-27.

11. Kępińska, B. Geothermal Energy Use-Country Update for Poland, 2016-2018. In Proceedings of the European Geothermal Congress, The Hague, The Netherlands, 11-14 June 2019.

12. Antics, M.; Bertani, R.; Sanner, B. Summary of EGC 2016 Country Update Reports on Geothermal Energy in Europe. In Proceedings of the European Geothermal Congress 2016 (CD), Strasbourg, France, 19-24 September 2016.

13. Clean Air, Ministry of Entrepreneurship and Technology. Available online: https://www.gov.pl/web/ przedsiebiorczosc-technologia (accessed on 25 October 2019).

14. Current Measurement Data for Air. Available online: http://powietrze.gios.gov.pl/pjp/current (accessed on 28 October 2019).

15. Zimolong, Z.; Barańska, B.; Galińska-Lizoń, D.; Werner, R. Five-Year Assessment of Air Quality in Opolskie Voivodship; Voivodship Report 2014-2018; Main Environment Protection Inspector: Opole, Poland, June 2019.

16. Marshal's Office of the Opolskie Voivodeship Department of Agriculture and Rural Development. Work Stage on the Use of Renewable Energy and Biofuels in the Opolskie Voivodeship; Marshal's Office of the Opolskie Voivodeship Department of Agriculture and Rural Development: Opole, Poland, 2007. 
17. Kalinowski, W. Renewable Energy balance of the Opole Voivodeship-Current state, development prospect. Sci. Works Inst. Glass Ceram. Refract. Constr. Mater. 2008, 2, 119-132.

18. Kozłowski, S. Mineral Resources of the Opolskie Voivodeship; Geological Publisher Warsaw: Warsaw, Poland, 1979.

19. Bujakowski, W.; Barbacki, A.; Pajakk, L. The possibilities of exploitation and development of geothermal waters in Nysa region. Tech. Poszuk. Geol. Geosynoptyka Geoterm. 2005, 6, 23-34.

20. Boguniewicz-Zabłocka, J.; Podgórni, E.; Kłosok-Bazan, I. The Impact of nano-silver doses on microorganism-deactivation effectiveness in water circulating in a cooling tower cycle. Pol. J. Environ. Stud. 2015, 24, 2321-2327.

21. Głodek, E.; Kalinowski, W. Development plan for renewable energy sources (RES) in the Opolskie Voivodeship. Renew. Sustain. Energy Rev. 2009, 14, 1336-1341.

22. Ciapała, B.; Janowski, M.; Jurasz, J. Ultra-low-temperature district heating with individual peak heat source in context of covering typical detached house heat demand. Tech. Poszuk. Geol. Geoterm. Zrównoważony Rozw. 2018, 2, 79-90.

23. Łukasiewicz, E.; Rzasa, M. Examination of coagulant additives on qualitative composition of selected thermal waters. E3S Web Conf. 2017, 19, 02013. [CrossRef]

24. Study for the Development of Energy Systems in: Opolskie Voivodeship 2015; Renewable Energy No. W-416.III; State Research Institute: Pulawy, Poland, 2003; Available online: http://archiwum.opolskie.pl/docs/03_ odnawialne.pdf (accessed on 28 October 2019).

25. Kolasa-Więcek, A. Development perspectives for renewable energy in the Opole Voivodeship. Barometr Regionalny Analizy i Prognozy 2012, 2, 107-114.

26. Kolasa-Więcek, A. The Current State of Renewable Energy Development in the Opolskie Voivodship. Barometr Regionalny 2015, 4, 89-98.

27. Kłosok-Bazan, I. Modeling of geothermal water deironing processes using artificial neural networks. In Proceedings of the 16th International Multidisciplinary Scientific Geoconference, Sgem 2016: Science and Technologies in Geology, Exploration and Mining, Albena, Bulgaria, 30 June-6 July 2016; Volume III, pp. 187-193.

28. Kłosok-Bazan, I. Innovations in industrial water preparation in a metallurgical plant. Metalurgija 2016, 55, 59-62.

29. Boguniewicz-Zablocka, J.; Klosok-Bazan, I.; Capodaglio, A.G.; Płoskonka, J. Planning the optimal solution for wastewater management in rural areas-Case study. In Proceedings of the MATEC Web of Conferences 174, Opole, Poland, 26 June 2018; Volume 2, p. 01035.

30. Pollutant Emission Calculator. Available online: http://vaillant-partner.pl/kalkulatory-on-line/kalkulatoremisji-zanieczyszczen/ (accessed on 24 October 2019).

31. Grzesiak, E. The Use of Geothermal Water for Heating Purposes on the Example of the Geothermal Heating Plant in Pyrzyce. Bechelor's Thesis, State University of Applied Sciences in Kalisz, Kalisz, Poland, 2007; p. 64 .

32. Socha, M.; Gryszkiewicz, I.; Stożek, J. Potential and prospects for using geothermal resources in Poland. PIG-PIB supporting medium-temperature geothermal development. In Deposit and Economic Geology; Program Polish Geological Institute-National Research Institute: Warsaw, Poland, 2019.

33. Tester, J.W.; Anderson, B.J.; Batchelor, A.S.; Blackwell, D.D.; DiPippo, R.; Drake, E.M.; Petty, S. The future of geothermal energy. In Impact of Enhanced Geothermal Systems (EGS) on the United States in the 21st Century; Massachusetts Institute of Technology: Cambridge, MA, USA, 2006; p. 372.

34. Dickson, M.H.; Fanelli, M. Geothermal Energy: Utilization and Technology; Routledge: Abingdon, UK, 2013.

35. Bombara, P.; Duvia, A.; Macchi, E. Combined, mixed, flash and binary cycles for electricity generation from geothermal sources. In Proceedings of the 20th NZ Geothermal Workshop, Auckland, New Zealand, 11-13 November 1998.

36. Clarke, J. Optimal Design of Geothermal Power Plants; Virginia Commonwealth University Richmond: Richmond, WV, USA, 13 May 2014.

37. Lund, J.W.; Boyd, T.L. Direct utilization of geothermal energy 2015 worldwide review. Geothermics 2016, 60, 66-93. [CrossRef] 
38. Kłonowski, M.R.; Kocyła, J.; Ryżyński, G.; Żeruń, M. Assessment of low-temperature geothermal energy potential based on analysis, interpretation and reclassification of geological data in urban areas. Tech. Poszuk. Geol. Geoterm. Zrównoważony Rozw. 2018, 2,19-38.

39. Renewable Energy in the Opole Region. Geothermal Energy. Available online: http://www.odnowawsi.eu (accessed on 1 February 2019).

40. Bologa, O.; Crenganis, M. Geothermal energy. In Proceedings of the ASTRA, Noordwijk, The Netherlands, 15-17 May 2013.

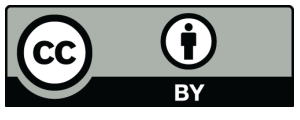

(C) 2019 by the authors. Licensee MDPI, Basel, Switzerland. This article is an open access article distributed under the terms and conditions of the Creative Commons Attribution (CC BY) license (http://creativecommons.org/licenses/by/4.0/). 